\title{
Quality Assessment and Shelf Life Evaluation of Ready to Eat [Fish Cutlet] of Bycatch Anchovies during Frozen Storage
}

\author{
R. Bharathipriya*, M. Satheesh, T. Sanjay, M. Gokul Prasanth, \\ S. Nimish Mol, S. Balasundari and N. Muralidharan
}

Dr. M. G. R Fisheries College and Research Institute, Ponneri, Tamilnadu Dr. J. Jayalalithaa Fisheries University, Nagapattinam, India

*Corresponding author

\author{
A B S T R A C T
}

\begin{tabular}{|l|}
\hline K e y w o r d s \\
Ready to eat, \\
Proximate \\
composition, \\
Biochemical, \\
Microbiological, \\
Organoleptic and \\
fish cutlet \\
\hline Article Info \\
\hline Accepted: \\
15 August 2019 \\
Available Online: \\
10 September 2019
\end{tabular}

\section{Introduction}

Consumers around the world have increased in consumption of fish and fishery product in recent years due to recognition of their nutritional value (Wang et al., 2010). Ready to eat or serve fishery products gaining good consumer preference. When it is prepared from by catch and discards, it further contributes to the economic growth of producers and as well as nation (Sowmya Praneetha et al., 2017). Shrimp trawl by catch

\begin{abstract}
An attempt was undertaken to evaluate the shelf-life of Ready To Eat (fish cutlet) of anchovies (Stolephorus commersonii). Fish cutlet was prepared by following standardized recipe and it was subjected to proximate composition, biochemical, microbiological and organoleptic analysis at an interval of three days during 18 days of storage period. Results for protein, lipid, ash and moisture indicates decreasing trend significantly from $15.14 \%$ to $13.26,12.33 \%$ to $10.55 \%, 2.86 \%$ to $2.47 \%$ and $60.59 \%$ to $57.22 \%$ ( $\mathrm{P}<0.05)$ respectively. However ${ }_{\mathrm{P}} \mathrm{H}$, Peroxide value, free fatty acid and Total volatile base Nitrogen depicted an increasing trend significantly ( $\mathrm{P}<0.05$ ) from 6.44 to $6.70,6.07$ to $11.87 \mathrm{meq} \mathrm{O}_{2} / \mathrm{kg}$ of fat, 2.13 to $5.01 \%$ of oleic acid and 3.85 to $20.32 \% \mathrm{mgN} / 100 \mathrm{~g}$ of sample respectively. TPC of bacteria was increased during storage day from $5.70 \times 10^{2}$ to $7.1 \times 10^{5} \mathrm{cfu} / \mathrm{g}$ of sample. Similarly the psychrophilic count was also increased from $2.6 \times 10^{2}$ to $6.8 \times 10^{4} \mathrm{cfu} / \mathrm{g}$ of sample. The organoleptic score for appearance, colour, taste, odour, texture and overall acceptability reduced significantly $(\mathrm{p}<0.05)$ with increase of storage period. Therefore an ideal shelflife for storing fish cutlet in refrigerated condition was found as 18 days.
\end{abstract}

like anchovies could be properly utilized by transforming low-valued fishes into value added product. During recent year's value addition have received more attention because of increased urbanization due to social and cultural changes (Pagarkar et al., 2011). There is great demand for seafood based product especially battered and breaded products. Battered and breaded or coated systems have the benefits of versatility and familiarity because they enhance the flavour and texture of processed food products (Biswas et al., 
2004). The process of canning with batter and bread crumbs increases the bulk of the product, thereby reducing the content of costly fish and thus reducing the cost of products, coating enhances the appearance, colour, texture, and taste of food products and also the nutritional value of the product (Rathod et al., 2012). However, there are almost no studies on fish cutlet developed from anchovies (Stolephorus commersonii). The aim of this study was to prepare fish cutlet from anchovies and to investigate quality changes for shelf-life evaluation viz., proximate, biochemical, microbiological and organoleptic analysis during refrigerated storage.

\section{Materials and Methods}

\section{Sample preparation}

Fresh by catches of anchovies (Stolephorus commersonii) with an average length and weight of 8-9 $\mathrm{cm}$ and 5-6 $\mathrm{g}$ were purchased from local market of Ponneri, Thiruvallur district. It was immediately transported to the processing lab within 20mins in polythene bags along with crushed ice. The head and visceral of anchovies were removed and cleaned fish was washed with large amount of water. The entire fish was boiled for 10 mins without removing bones, after that it was finally minced using domestic mincer to prepare fish cutlet.

Shaped cutlet was battered by dipping it in egg and rolled in bread crumbs powder. After battering that was flash fried at $180^{\circ} \mathrm{C}$ for 30 sec. The product were later cooled, packed in HDPE pouches, sealed, labelled and stored at frozen storage for quality evaluation. Samples were drawn randomly in duplicates at 3 days intervals up to 18 days of frozen storage to analyse proximate, biochemical, microbiological and organoleptic parameters. All the parameters were analysed in triplicate from initial to final storage day.

\section{Analysis}

\section{Proximate analysis}

Proximate composition viz, moisture, crude protein, fat, ash of fish cutlet were analysed according to AOAC method (2005).

\section{Bio chemical analysis}

$\mathrm{pH}$ was determined by taking sample $(5 \mathrm{~g})$ and added with $45 \mathrm{ml}$ of distilled water. Then filtered using a filtered paper. The $\mathrm{pH}$ of filtrate was recorded using $\mathrm{pH}$ meter AOAC method (2005). Peroxide value (PV) was measured using titrimetric determination of amount of peroxide or hydro peroxide groups, $\mathrm{PV}$ was expressed as milli equivalent of $\mathrm{O}_{2} /$ $\mathrm{kg}$ fat AOAC method (2005). Free fatty acid (FFA) value was determined as per AOAC method (2005) and expressed as percent (\%) of oleic acid. TVBN contents were determined by procedure given by Beatty and Gibbons (1937) using Conway micro-diffusion units and results were expressed in terms of nitrogen $\mathrm{mg} / 100 \mathrm{~g}$.

\section{Sensory analysis}

Organoleptic quality of fish cutlets were evaluated using nine point hedonic scale [1dislike extremely to 9- like extremely]. Experienced members of the institute were indulged in the panel for evaluating the product acceptability. The characteristics covered under the panel were appearance, colour, odour, flavour, taste, texture and overall acceptability (Reddy, 1992).

\section{Statistical analysis}

Statistical package was used for analysis of experimental results. Sufficient number of samples was carried out for each analysis. The results were expressed as mean \pm standard deviation(SD).The significant differences 
were tested by $5 \%$ level of significance and are mentioned as $(\mathrm{P}<0.05)$ for significances difference by Snedecor and Cochran (1967).

\section{Results and Discussion}

\section{Proximate composition}

The percentage of proximate composition like moisture, protein, fat, and ash content of fresh anchovies (Stolephorus commersonii) were $78.39 \pm 0.38, \quad 17.14 \pm 0.87, \quad 2.34 \pm 0.30$ and $1.98 \pm 0.25$ respectively. Similarly with slight variation was reported by (Palanikumar et al., $2014)$ as moisture $(79.32 \pm 0.17)$, protein $(16.32 \pm 0.93)$, lipid $(2.41 \pm 0.17)$ and ash $(1.31 \pm 0.02)$ contents in fresh anchovies, whereas (Chao minh le et al., 2015) reported the moisture, protein, fat, and ash content in fresh anchovies were $78.3 \pm 0.7,16.3 \pm 0.3$, $2.4 \pm 0.3$ and $2.5 \pm 0.4$ respectively. The moisture, protein, fat, and ash of anchovies fish cutlet were found to be $60.59 \pm 1.66$, $15.14 \pm 0.84, \quad 12.33 \pm 0.28$ and $2.86 \pm 0.72$ respectively which at the end of storage period, it showed the variation in proximate composition of the moisture, protein, fat, and ash content of fish cutlet were decreased from $60.59 \pm 1.66$ to $57.22 \pm 1.71 \%, 15.14 \pm 0.84 \%$ to $13.26 \pm 1.19 \%, 12.33 \pm 0.28$ to $10.55 \pm 0.33 \%$ and $2.86 \pm 0.72 \%$ to $2.47 \pm 0.52 \%$ respectively. Reddy et al., (1992) reported decrease in moisture content in fish cutlet prepared from reef $\operatorname{cod}$ mince. The reduction of protein is due to denaturation of fish muscle during chilled and frozen storage (Gopakumar, 2002). Sehgel et al., (2010) suggested that cooking can be a possible reason for reduction in the protein content. Similarly, the decrease in lipid content has been reported by siddique et.al. (2011) in Puntius spp. Oxidation of fat in product led to reduction in fat content (Mc Gill et al., 1974; Josephson, 1989). Also, the decrease in ash content could be due to drip loss resulting in loss of bulk and trace elements (Gandotra et al., 2014). In the present study, it was observed that moisture, protein, fat, and ash content of fish cutlet put together as $91 \%$ and the remaining percentage might be contributed by carbohydrates (Takur et al., 2006). Addition of coating materials like bread crumbs gives higher percentage of carbohydrate content to the product (Sayar, 2011).

\section{Biochemical change}

\section{pH}

The ${ }_{\mathrm{P}} \mathrm{H}$ of fish cutlet increased from $6.44 \pm 0.09$ to $6.70 \pm 0.09$. It might be due to decomposition of nitrogenous components in post-mortem. Bett and Dionigi, (1977); Turhan et al., (2001) reported $\mathrm{pH}$ increase is attributed due to release of $\mathrm{CO}_{2}$ by microbial flora present in product. Enzymatic degradation increases the $\mathrm{pH}$ in fish muscle (Love, 1992 and Vareltiset et al., 1997). Breakage of hydrogen bond and electrostatic interaction leads to increase in $\mathrm{pH}$ (Dhanpal et al., 2012). Pawar (2011) reported increasing trend of $\mathrm{pH}$ for cutlet made from catla fish from 6.50 to 6.79 at -2 to $-4^{\circ} \mathrm{C}$. Similar observation was also made by the Kilinc, (2007) during refrigeration storage of fish patties produced from anchovy. Increasing trend in $\mathrm{pH}$ has been observed by Rathod and Pagarkar (2013) in Pangasius fish cutlets.

\section{Peroxide value}

Peroxide value of fish cutlet during the initial storage period increased from $6.07 \pm 0.23$ to $14.65 \pm 2.54 \mathrm{meq} \mathrm{O}_{2} / \mathrm{kg}$ of fat at the end of $12^{\text {th }}$ day storage and after that PV value subsequently decreased to $11.87 \pm 0.69 \mathrm{meq}$ $\mathrm{O}_{2} / \mathrm{kg}$ of fat at the end of $18^{\text {th }}$ day of storage. (Kamat, 1999) reported that PV of mackerel mince cutlet was increased from an initial value of 3.4 to $40 \mathrm{meq} \mathrm{O}_{2} / \mathrm{kg}$ at the end of $5^{\text {th }}$ week of storage at $-14^{\circ} \mathrm{C}$ respectively. PV value of fish burger prepared from tilapia 
(Oreochromis niloticus) was $0.18 \mathrm{meq} / \mathrm{kg}$ at the beginning of storage period and increased to $5.03 \mathrm{meq} / \mathrm{kg}$ at the $6^{\text {th }}$ month and then decreased to $0.82 \mathrm{meq} / \mathrm{kg}$ at the end of $8^{\text {th }}$ month (Tokur et al., 2006). The unstable nature of $\mathrm{PV}$ is due to decomposition of peroxides and its products may internet with protein, which results in PV reduction (Yerlikaya et al., 2005).

\section{FFA}

FFA of anchovies fish cutlet showed an increasing trend from $2.13 \pm 0.36$ to $5.01 \pm 0.21$ $\mathrm{mg} / 100 \mathrm{~g}$. Similar results with slight variation were reported by Nikheel Rathod and Asif Pagarkar (2013) with increase in FFA of pangasius fish cutlet from 1.26 to 4.83 $\mathrm{mg} / 100 \mathrm{~g}$. FFA is a result of enzymatic decomposition of lipid during storage (Tokur et al., 2006). Cooking of minced meat might have deactivated the lipolytic enzymes and subsequent flash frying of product led to increase in FFA (Ninan et al., 2011). FFA content showed variation in fresh fried and raw cutlet in the range of 0.98 to 1.49 and 2.03 to $2.82 \mathrm{mg} / 100 \mathrm{~g}$ respectively at $4^{\circ} \mathrm{C}$ (Joseph $e t$ al., 1984). Tokur et al., (2006) also reported increased FAA from the begining of the storage period up to $8^{\text {th }}$ month.

\section{TVBN (Total Volatile base Nitrogen)}

TVBN is known as a product of bacterial spoilage and is a commonly used chemical method to determine spoilage of fish (Tokur $e t$ al., 2004). TVBN value of anchovies cutlet showed increasing trend from $3.85 \pm 0.19$ to $20.32 \pm 0.95$ during storage period. Increase of TVBN content during storage is due to bacterial spoilage, activity of endogenous enzymes and degradation of tissue proteins (Chomnawang et al., 2007) or production of ammonia (Adebona, 1978). TVBN value of pangasius fish cutlet showed increased trend from 2.52 to $22.4 \mathrm{mg} / 100 \mathrm{~g}$ Nikheel Rathod and Asif Pagarkar, (2013). Bao et al., (2007) reported increasing trend of TVBN in arctic charr (Salvelinus alpines) fillets at chilled storage temperature. TVBN value of tilapia fish cutlet was increased in the range of 12.4 to $20.2 \mathrm{mg} \%$ respectively (Ninan et al., 2008).

Table.1 Using standardized recipe the cutlets were prepared (Pawar et al., 2011)

\begin{tabular}{|c|c|}
\hline INGREDIENTS & QUANTITY(g) \\
\hline Cooked fish meat & 100 \\
\hline Table salt & 3 \\
\hline Green chilly & 5 \\
\hline Coriander leaves & 5 \\
\hline Ginger & 5 \\
\hline Garlic & 5 \\
\hline Onion & 25 \\
\hline Potato cooked & 70 \\
\hline Pepper powder & 0.3 \\
\hline & \\
\hline Clove powder & 0.3 \\
\hline Cinnamon powder & 0.2 \\
\hline Burmeric powder & 0.2 \\
\hline
\end{tabular}

Oil - Sunflower oil was used (10ml) for heating purpose 
Table. 2 proximate composition of raw meat, initial and final day of cutlet

\begin{tabular}{|c|c|c|c|}
\hline Attributes & Raw meat & Cutlet Initial day & Cutlet Final day \\
\hline Moisture & $78.39 \pm 0.38$ & $60.59 \pm 1.66$ & $57.22 \pm 1.71$ \\
\hline Protein & $17.14 \pm 0.87$ & $15.14 \pm 0.84$ & $13.26 \pm 1.19$ \\
\hline Fat & $2.34 \pm 0.30$ & $12.33 \pm 0.28$ & $10.55 \pm 0.33$ \\
\hline Ash & $1.98 \pm 0.25$ & $2.86 \pm 0.72$ & $2.47 \pm 0.52$ \\
\hline
\end{tabular}

Table.3 proximate composition of cutlet during storage days

\begin{tabular}{|c|c|c|c|c|}
\hline Storage duration (days) & Moisture (\%) & Protein (\%) & Fat (\%) & Ash (\%) \\
\hline $\mathbf{0}$ & $60.59 \pm 2.04^{\mathrm{a}}$ & $15.14 \pm 1.03^{\mathrm{a}}$ & $12.33 \pm 0.34^{\mathrm{e}}$ & $2.86 \pm 0.89^{\mathrm{a}}$ \\
\hline $\mathbf{3}$ & $60.11 \pm 2.07^{\mathrm{a}}$ & $14.84 \pm 1.12^{\mathrm{a}}$ & $12.06 \pm 0.25 \mathrm{~d}^{\mathrm{e}}$ & $2.80 \pm 0.87^{\mathrm{a}}$ \\
\hline $\mathbf{6}$ & $59.66 \pm 2.02^{\mathrm{a}}$ & $14.64 \pm 1.21^{\mathrm{a}}$ & $11.75 \pm 0.20^{\mathrm{cd}}$ & $2.72 \pm 0.88^{\mathrm{a}}$ \\
\hline $\mathbf{9}$ & $59.14 \pm 1.66^{\mathrm{a}}$ & $14.30 \pm 1.23^{\mathrm{a}}$ & $11.48 \pm 0.23^{\mathrm{bc}}$ & $2.66 \pm 0.82^{\mathrm{a}}$ \\
\hline $\mathbf{1 2}$ & $58.77 \pm 1.70^{\mathrm{a}}$ & $13.83 \pm 1.47^{\mathrm{a}}$ & $11.08 \pm 0.26^{\mathrm{ab}}$ & $2.62 \pm 0.79^{\mathrm{a}}$ \\
\hline $\mathbf{1 5}$ & $57.93 \pm 2.06^{\mathrm{a}}$ & $13.55 \pm 1.60^{\mathrm{a}}$ & $10.98 \pm 0.33^{\mathrm{a}}$ & $2.59 \pm 0.77^{\mathrm{a}}$ \\
\hline $\mathbf{1 8}$ & $57.22 \pm 2.09^{\mathrm{a}}$ & $13.26 \pm 1.46^{\mathrm{a}}$ & $10.55 \pm 0.41^{\mathrm{a}}$ & $2.47 \pm 0.64^{\mathrm{a}}$ \\
\hline
\end{tabular}

Each value is represented as the mean $\pm S D$ of $n=3$

${ }^{\text {abcde }}$ Means followed by the same superscript within a column

Table.4 Biochemical changes in cutlet during storage

\begin{tabular}{|c|c|c|c|c|}
\hline $\begin{array}{c}\text { Storage duration } \\
\text { (days) }\end{array}$ & $\mathbf{p H}$ & $\begin{array}{c}\text { PV(meq O2/kg } \\
\text { of fat) }\end{array}$ & $\begin{array}{c}\text { TVBN(mg/100g of } \\
\text { sample) }\end{array}$ & $\begin{array}{c}\text { FFA (\% of oleic } \\
\text { acid) }\end{array}$ \\
\hline $\mathbf{0}$ & $6.44 \pm 0.09^{\mathrm{a}}$ & $6.07 \pm 0.23^{\mathrm{a}}$ & $3.85 \pm 0.19^{\mathrm{a}}$ & $2.13 \pm 0.36^{\mathrm{a}}$ \\
\hline $\mathbf{3}$ & $6.48 \pm 0.10^{\mathrm{ab}}$ & $7.78 \pm 1.08^{\mathrm{b}}$ & $5.04 \pm 1.13^{\mathrm{a}}$ & $2.55 \pm 0.32^{\mathrm{a}}$ \\
\hline $\mathbf{6}$ & $6.52 \pm 0.10^{\mathrm{abc}}$ & $9.16 \pm 0.78^{\mathrm{c}}$ & $8.45 \pm 1.80^{\mathrm{b}}$ & $3.24 \pm 0.41^{\mathrm{b}}$ \\
\hline $\mathbf{9}$ & $6.56 \pm 0.10^{\mathrm{abc}}$ & $11.76 \pm 0.87^{\mathrm{d}}$ & $11.22 \pm 2.41^{\mathrm{bc}}$ & $3.88 \pm 0.44^{\mathrm{b}}$ \\
\hline $\mathbf{1 2}$ & $6.61 \pm 0.10^{\mathrm{abc}}$ & $15.26 \pm 0.61^{\mathrm{e}}$ & $14.65 \pm 2.54^{\mathrm{cd}}$ & $4.33 \pm 0.48^{\mathrm{c}}$ \\
\hline $\mathbf{1 5}$ & $6.64 \pm 0.10^{\mathrm{bc}}$ & $14.09 \pm 0.74^{\mathrm{e}}$ & $17.22 \pm 1.62^{\mathrm{d}}$ & $4.59 \pm 0.37^{\mathrm{c}}$ \\
\hline $\mathbf{1 8}$ & $6.70 \pm 0.09^{\mathrm{c}}$ & $11.87 \pm 0.69^{\mathrm{d}}$ & $20.32 \pm 0.95^{\mathrm{d}}$ & $5.01 \pm 0.21^{\mathrm{d}}$ \\
\hline
\end{tabular}

Table.5 Microbiological changes in cutlet during storage

\begin{tabular}{|c|c|c|}
\hline Storage period (days) & $\begin{array}{c}\text { Total plate count (cfu/g of } \\
\text { sample) }\end{array}$ & $\begin{array}{c}\text { Psychrophilic count (cfu/g } \\
\text { of sample) }\end{array}$ \\
\hline $\mathbf{0}$ & $5.7 \times 10^{2}(2.75)$ & $2.6 \times 10^{2}(2.41)$ \\
\hline $\mathbf{3}$ & $2.8 \times 10^{3}(3.44)$ & $5.3 \times 10^{2}(2.72)$ \\
\hline $\mathbf{6}$ & $4.0 \times 10^{3}(3.60)$ & $7.9 \times 10^{2}(2.89)$ \\
\hline $\mathbf{9}$ & $1.23 \times 10^{4}(4.08)$ & $1.4 \times 10^{3}(3.14)$ \\
\hline $\mathbf{1 2}$ & $5.8 \times 10^{4}(4.76)$ & $6.5 \times 10^{3}(3.81)$ \\
\hline $\mathbf{1 5}$ & $3.6 \times 10^{5}(5.55)$ & $2.3 \times 10^{4}(4.36)$ \\
\hline $\mathbf{1 8}$ & $7.1 \times 10^{5}(5.85)$ & $6.8 \times 10^{4}(4.83)$ \\
\hline
\end{tabular}


Table.6 Organoleptic changes in cutlet during storage

\begin{tabular}{|c|c|}
\hline Storage period (days) & Overall acceptability score \\
\hline $\mathbf{0}$ & $8.89 \pm 0.11^{\mathrm{g}}$ \\
\hline $\mathbf{3}$ & $8.45 \pm 0.14^{\mathrm{f}}$ \\
\hline $\mathbf{6}$ & $7.62 \pm 0.16^{\mathrm{e}}$ \\
\hline $\mathbf{9}$ & $6.71 \pm 0.18^{\mathrm{d}}$ \\
\hline $\mathbf{1 2}$ & $6.23 \pm 0.17^{\mathrm{c}}$ \\
\hline $\mathbf{1 5}$ & $5.48 \pm 0.24^{\mathrm{b}}$ \\
\hline $\mathbf{1 8}$ & $4.63 \pm 0.23^{\mathrm{a}}$ \\
\hline
\end{tabular}

Each value is represented as the mean $\pm \mathrm{SD}$ of $\mathrm{n}=3$

${ }_{\text {abcdefg }}$ Means followed by the same superscript with in a column

Chart.1 Organoleptic evaluation of fish cutlet

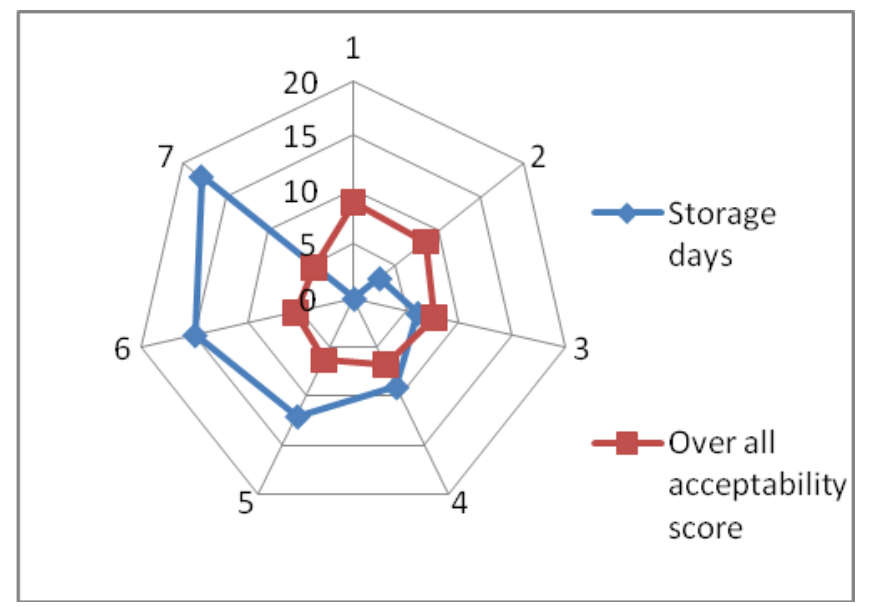

\section{Microbiological changes}

The changes in total plate count and psychrophilic bacterial count were enumerated for fish cutlet during storage period. TPC was increased from $5.7 \times 10^{2}$ $(2.75)$ to $7.1 \times 10^{5}(5.85) \mathrm{cfu} / \mathrm{g}$. Similarly the psychrophilic count was also increased from $2.6 \times 10^{2}(2.41)$ to $6.8 \times 10^{4}(4.83) \mathrm{cfu} / \mathrm{g}$ during storage. The same increase of bacterial count was observed by Joseph et al., (1984) in fish cutlet during storage at $4^{0} \mathrm{C}$. Similar increasing trend of bacterial count was reported by (Sowmya praneetha et al., 2017), However, this level did not exceed the maximum limit (7 log cfu/g for meat) as described by ICMSF (1978). Pathogenic and spoilage bacterial like salmonella spp., vibrio spp. and Escherichia coli were not detected in fish cutlet, this could be due to flash frying of the product.

\section{Organoleptic evaluation}

Score of sensory attributes like appearance, colour, taste, texture and odour were assessed and the mean value for overall acceptability score (OAS) was determined. It could be observed that overall mean acceptability score reduced significantly with increase of storage period. The ideal shelf life for storing anchovies fish cutlet at frozen storage condition was found to be 18 days.

It is concluded that, in recent years, increase of world population as well as various socio 
economic changes led to an increased consumer preference for ready to eat food. From this attempt, quality and shelf life of fish cutlet were assessed, where all the quality criteria mentioned above are well below the maximum limit for the acceptability fish cutlets. This study will give an idea on shelf life stability and quality of fish cutlet during frozen storage and it will be useful for retailers and large scale food marketers.

\section{Acknowledgment}

The authors wish to express their profound gratitude to the Dean, Dr. M.G.R Fisheries College and Research institute, Ponneri for providing facilities and support during the practical work.

\section{References}

Adebona, M.B., (1978). Changes in total volatile bases during salt preservation of Sardinellaeda and Clupeaharengus. IPFC proceedings, monila, Philippines, (8-11 March 1978), pp. 370-374.

AOAC, (2005) Official Methods of Analysis, Association of Official Analytical Chemists International, 18th edition, In: Horwitz, W. (Ed.), AOAC, Washington (D. C.), 35: 2-36.

Bao HND, Arason S and Porarinsdottir KA (2007). Effect of dry ice and super chilling on quality and shelf life of Arctic Charr (Salvelinus alpines) fillets. International Journal of Food Engineering 3(3) 1-27.

Beatty, S. A. and Gibbons, N. E. (1937). The measurement of spoilage in fish. J. Biol. Bd. Can., 3: 77-91.

Biswas, A. K., Kesari, R.C. and Bisht, G.S. (2004) Effect of enrobing and antioxidants on quality characteristics of precooked pork patties under chilled and frozen storage condition. Meat Science, 66 (3): 733-741pp.
Bochi, V.C., Weber, J., Ribeiro, C.P., Victörio, A.M. and Emanuelli, F. 2008. Fishburgers with silver catfish (Rhamdiaquelen) filleting residue. Bioresource Technology 99: 8844-8849

Chau Minh Le et al. Proteolysis of Sardine (Sardina pilchardus) and Anchovy (Stolephorus commersonii) by Commercial Enzymes in Saline Solutions. Food Technol. Biotechnol. 53 (1) 87-90 (2015) doi: 10.17113/ b.53.01.15.3893.

Chomnawang, $\quad$ C., Nantachai, $\quad K$., Yongsawatdigul, $\quad J$, Thawornchinsombut, $S$ and Tungkawachara, S. (2007) Chemical and biochemical changes of hybrid catfish fillet stored at $40 \mathrm{C}$ and its gel properties. Food Chemistry, 103:420427.

Conway, E. J. 1962.Microdiffusion Analysis of Volumetric Error, 5th ed. Crospy Lockwood and Son Ltd., London.

Dhanapal, K. 1992. Processing of chank (Xancus pyrum) meat by different methods. M.F.Sc thesis. Tamil Nadu Veterinary and Animal Sciences University, Tamil nadu, India. Pp. 62.

Gandotra R, Gupta V, Koul M, Gupta S, Parihar D, Kumari R. The Effect of Ascorbic Acid and Citric Acid Solution Treatment on the Flesh Quality of Wallago attu. Int. J. Sci. Technol., 2014; 2(6):110-115

Gopakumar, K., 1988. Utilisation of low grade marine fish. In: Sinha, V. R. P. and Srivastava, H. C. (ed.), Aquaculture Productivity. Oxford and IBH Publishing Co., New Delhi, pp. 719729.

Gopakumar, K. (2002) Biochemical composition of fish In: Textbook of Fish Processing Technology, Directorate of information and publishing of agriculture. ICAR, New Delhi. 
Joseph J. and Perigreen P.A. and Thampuran N. (1984) Preparation and Storage of Cutlet from Low-priced Fish. Fishery Technol., 21: 70-74.

Kamat A. H. (1999) Preparation of Fish ball and Fish cutlet from Mackerel Mince Meat. M.F. Scthesis submitted to Konkan Krishi Vidyapeeth, Dapoli, Maharashtra 200 pp- 200.

Kilinc, B. 2007. Microbiological, sensory and color changes of anchovy (Engraulis encrasicholus) patties during refrigerated storage. Journal of Muscle Foods, 20:129-137

Love RM (1992). Biochemical dynamics and the quality of fresh and frozen fish. Fish Processing Technology, Editors: Hall GM, (Chapman and Hall) 1-30.

MacGill AS, Hard R, Burt JR. Hept-cis-4enal and its contribution to the off flavor in cold stored cod. Journal of Science Food and Agricultural 1974; 25:1477-1489.

Ninan G., Joseph A.C., Zynudheen A.A., Abbas, A.R. and Ravishankar C.N. (2010) Effect of hydrocolloids as an ingredient of batter mix on the biochemical, physical and sensory properties of frozen stored coated shrimp. Fish. Technol., 47(1): 57-64.

Palani kumar et al., Proximate and Major Mineral Composition of 23 Medium Sized Marine Fin Fishes Landed in the Thoothukudi Coast of India. J Nutr Food Sci 2014, 4:1 DOI: 10.4172/21559600.1000259.

Pagarkar A.U., Joshi V.R., Baug T. E. and Kedar J.G., (2011). Value addition is need of seafood industries. FISHCOOPS, 23 (4): 8-17pp.

Rathod N. and Pagarkar A. (2013), Biochemical and Sensory quality changes of fish cutlets, made from pangasius fish (pangasianodon hypophthalmus), during storage in refrigerated display unit at -15 to -18 oc.
International Journal of Food, Agriculture and veterinary sciences. Vol. 3 (1) January - April, 1-8pp.

Rathod, N. B., Pagarkar, A. U., Pujari, K. H., Gokhale, N. B. And Joshi, V. R. (2012) Standardisation of recipe for fish cutlet product from Pangasianodon hypophthalmus. Eco. Env. Cons. 18 (4): 2012; pp. (1-6).

Reddy L., Setty T.M.R and Dora K.C. (1992) Studies on the Storage Behaviour of Frozen Fish Fingers from croaker and perches. Fish. Technol., 29: 35-39.

Reddy, G.V.S. 1992.Development of ready to serve fish products using lactic fermentation, 44. Ph.D. Thesis, University of Agricultural Science, Bangalore.

Sayar, S. 2001. A study on production of croquet from whiting fillets (Merlangiusmer langiuseuxinus L., 1758). Under graduate thesis. Ege University, Faculty of Fisheries, Izmir, Turkey. P: 25.

Sehgal, H.S and Sehgal, G. K. 2002.Aquacultural and socio-economic aspects of processing carps into some value-added products. Bioresource Technology, 82:291-293.

Sehgal, H.S., Sehgal, G.K., Thind, S.S., Kaur, A and Rehal, J. 2010. Development of "fish mince pakora" from a cultured carp species, Labeo rohita (Ham.) Journal of Food Processing and Preservation, 34:15-23.

Siddaiah, D., Reddy, G.V.S., Raju, C.V and Chandrasekhar, T.C. 2001. Changes in lipids, proteins and kamaboko forming ability of silver carp (Hypophthalmich thysmolitrix) mince during frozen storage. Food Research International, 34:47-53.

Snedecor, G.W. and Cochran, W.G. (1967) In: Statistical methods, Sixth ed. Oxford and IBH CO., New Delhi, 593 pp.

Sowmya S.P., Dhanapal K., Reddy G.V.S., 
Balasubramanian A. and Praveen Kumar G. (2017). Studies on the Quality of fish cutlet prepared from Rohu (Labeo rohita) during refrigerated storage. Int. Curr. Microbiol. App. Sci. 6 (12): 3262-3271pp.

Tokur B, Ozkütük S, Atici E, Ozyurt G and Ozyurt CE (2006). Chemical and sensory quality changes of fish fingers, made from mirror carp (Cyprinus carpio L, 1758), during frozen storage $\left(-18^{\circ} \mathrm{C}\right)$. Food Chemistry 99(2) 335341 .

Vareltzis K., Koufidis D., Gavriilidou E., Papavergou E. and Vasiliadou S. (1997)
Effectiveness of a natural Rosemery (Rosmarinus officinalis) extract on the stability of filleted and minced fish during frozen storage. European Food Res. and Technol., 205:93-96.

Wang T, Zhang J and Zhang X (2010). Fish quality evaluation based on temperature monitoring in cold chain. African Journal of Biotechnology 9(37) 61466151

Yerlikaya, P., Gokoglu, N and Uran, H. 2005. Quality changes of fish patties produced from anchovy during refrigerated storage. European Food Research Technology, 220: 287-291.

\section{How to cite this article:}

Bharathipriya, R., M. Satheesh, T. Sanjay, M. Gokul Prasanth, S. Nimish Mol, S. Balasundari and Muralidharan, N. 2019. Quality Assessment and Shelf Life Evaluation of Ready to Eat [Fish Cutlet] of Bycatch Anchovies during Frozen Storage. Int.J.Curr.Microbiol.App.Sci. 8(09): 267-275. doi: https://doi.org/10.20546/ijcmas.2019.809.032 